\title{
Ravnanje z znanjem v javni upravi
}

\author{
UDK: 35658.652
}

\author{
Nina Tomaževič \\ Univerza v Ljubljani, Fakulteta za upravo \\ nina.tomazevic@fu.uni-lj.si
}

\section{IZVLEČEK}

Pričakovanja udeležencev ${ }^{1} \mathrm{v}$ poslovanju organizacij slovenske javne uprave so zaradi sprememb v ožjem (država, regija) in širšem okolju (EU, svet) vse večja. Navedeno dejstvo organizacije javne uprave sili in spodbuja $k$ uvedbi, uporabi in nadgradnji sodobnih konceptov menedžmenta $z$ namenom izboljšanja učinkovitosti in uspešnosti poslovanja, inovativnosti ter poslovne odličnosti. Organizacije javne uprave bodo morale postati dinamične v smislu sledenja spremembam v okolju in v njih samih. Pri tem je in bo znanje ključno strateško sredstvo, ki ga bo za namen izboljševanja storitev treba učinkovito poiskati, pridobivati, deliti, povečevati, zavarovati in uporabljati ter preverjati njegov vpliv na uspešnost poslovanja. Članek pojasnjuje koncept ravnanja $z$ znanjem nasploh, $v$ javni upravi in stanje na obravnavanem področju v slovenski javni upravi.

Ključne besede: ravnanje z znanjem, znanje, javna uprava, novi javni menedžment, ravnanje z ljudmi

\section{Uvod}

Precej organizacij je že spoznalo, da njihova učinkovitost in uspešnost nista odvisni samo od tehnologije, naravnih in finančnih virov, vplivov okolja ter drugih dejavnikov, ki vplivajo na poslovanje, saj so ti enako dostopni oz. v enaki meri veljajo za večino organizacij. Kakšna bo prihodnost organizacije v letih, ki prihajajo, je odvisno predvsem od znanja in pristopa $k$ ravnanju z njim, ki ga imajo zaposleni danes. Pri tem je ključnega pomena razumevanje koncepta ravnanja z znanjem kot načina vsakodnevnega delovanja zaposlenih in njihovih vodij, kar pa bo za večino organizacij pomenilo nujno preoblikovanje obstoječih struktur organiziranosti, procesov v organizaciji in organizacijske kulture. Le tako ravnanje z znanjem ne bo le ena od modnih muh na področju informacijsko-komunikacijske

1 'Udeleženci' kot prevod izraza 'stakeholders'. 


\section{Nina Tomaževič \\ Ravnanje z znanjem $v$ javni upravi}

tehnologije, kot se je izkazalo $v$ nekaterih podjetjih ob uvajanju informacijskih sistemov za ravnanje z znanjem. Javne uprave razvitih držav se soočajo $z$ enakim problemom: javnost (zasebna in poslovna) želi boljše storitve, in to brez povečanja stroškov (davkov). Navedeno dejstvo organizacije javne uprave sili k ukrepanju $v$ smeri iskanja notranjih rezerv, predvsem na področju ravnanja $z$ ljudmi. Ker so v ljudeh skriti največji (še) neizkoriščeni potenciali in ker so ljudje ena največjih konkurenčnih prednosti posamezne organizacije, so ustrezni pristopi na področju ravnanja z ljudmi še kako pomembni.

Sodobne države morajo, zaradi razmer $v$ svetovnem gospodarstvu, poleg uspešnega in učinkovitega zasebnega sektorja razvijati in izboljševati tudi (konkurenčen) javni sektor. $V$ evropskem prostoru so za to področje postavljeni cilji $\vee$ lizbonski strategiji. Mnoge države se $\vee$ ta namen lotevajo reform javnega sektorja, ki jih na kratko lahko opredelimo kot "premišljene spremembe struktur in procesov $v$ organizacijah javnega sektorja s ciljem, da delujejo bolje" (Pollit, Bouckaert, 2004, str. 8). Tudi slovenska javna uprava se prilagaja spremembam $\checkmark$ okolju. Modernizacija struktur in procesov organiziranosti se odvija z uvajanjem in uporabo sodobnih konceptov menedžmenta. Cilj prispevka je predstaviti koncept ravnanja z znanjem z namenom, da bi se zavedanje o njegovem pomenu začelo širiti $v$ organizacije slovenske javne uprave in javnega sektorja in bi vplivalo tudi na pospešeno uvajanje ter uspešno uporabo omenjenega koncepta.

Prispevek je sestavljen iz petih delov. $\mathrm{V}$ prvem je obravnavan pojem znanja, da lahko $v$ drugem pojasnimo pojem ravnanja z znanjem in $v$ tretjem pojem sistemov za ravnanje $z$ znanjem. Po opredelitvi navedenih pojmov $v$ četrtem delu sledi utemeljitev pomembnosti ravnanja $z$ znanjem $v$ javni upravi ter $\vee$ petem delu pregled področij, ki se nanašajo na obravnavano temo $\vee$ slovenski javni upravi.

\section{Znanje}

\subsection{Opredelitev in vrste znanja}

Znanje je zbir izkušenj, vrednot in informacij, ki omogoča ocenjevanje in razvijanje novih izkušenj in informacij (Davenport, Prusak, 1998, str. 5). Podatki (urejena zaporedja znakov, stvari, dogodkov, npr. številke, podobe, besede, zvoki) in informacije (podatki, postavljeni v kontekst - ko dobijo pomen in namen), kar mnogi razumejo kot znanje, so torej le del $\vee$ procesu pridobivanja 


\section{Nina Tomaževič \\ Ravnanje z znanjem $v$ javni upravi}

znanja. Ko informacije pri delu dejansko uporabimo, ko jim dodamo kontekst, določen pomen in namen za izboljšanje delovne uspešnosti posameznika in končno tudi uspešnosti organizacije, se razvije znanje (Sitar v: Možina, Kovač, 2006, str. 62).

Avtorji na področju ravnanja z znanjem, na primer Smith (2001), ločijo prikrito (tacit) in odkrito (explicit) znanje. Prikrito znanje je subjektivno in sloni na izkustvenem učenju. Ljudje ga nosijo v sebi, zato je težko dostopno. Ljudje se ga pogosto ne zavedajo ali pa se ne zavedajo vrednosti, ki jo to znanje pomeni drugim. Učinkovit prenos prikritega znanja zahteva običajno osebni stik in zaupanje. Prikrito znanje je znanje posameznika, pri čemer ga 'nosilec znanja' težko opiše in posreduje drugim članom organizacije. Prikrito znanje sestavljajo izkušnje, sposobnosti, intuicija, razumevanje, prepoznavanje, zaznavanje, občutki in čustva (Sitar v: Možina, Kovač, 2006, str. 64). Znanje, ki ga ni težko posredovati drugim, je odkrito (explicit) znanje. Proces pretvorbe prikritega $\vee$ odkrito znanje imenujemo kodiranje. Odkrito znanje je zajeto $v$ tekstih, tabelah, diagramih, specifikacijah izdelkov, znanstvenih formulah, računalniških programih, podatkovnih bazah, zapisanih dobrih praksah in standardih (Sitar v: Možina, Kovač, 2006, str. 63).

Prikrito znanje je vtkano $v$ organizacijo in organizacijska razmerja, ključne vrednote, predvidevanja in prepričanja. Težko ga je identificirati, locirati, planirati ali vrednotiti. Pomembno je kot strateška prednost pred tekmeci $v$ smislu inovacij, idej in novih tehnologij.

Hitrost sprememb v poslovanju zahteva hitre rešitve, ki jih je po Lipičniku (2001, str. 13) skoraj nemogoče doseči z ustaljenim znanjem. Slednje predstavlja sklop preverjenih odločitev iz preteklosti, ki so se takrat izkazale kot dobre, novim ali drugačnim zahtevam pa marsikdaj ne ustrezajo. Tem zahtevam bo treba postreči z izvirnostjo, ki je pogosta posledica kreativnosti posameznikov in družbe kot celote. Izvirnost običajno le s težavo spodrinja stare navade, ki jih vključuje tudi preteklo znanje. Znanje je torej svojevrstna ovira kreativnosti, saj zaradi svoje trdovratnosti ne dopušča, da bi uvideli nove priložnosti, ki ležijo izven našega znanja. Znanje, ki ga imamo, nas torej lahko tudi ovira, da bi kreativno razmišljali $\vee$ novih razmerah, zato bo $v$ marsikaterem primeru treba stara znanja ne samo pozabiti, ampak se tudi 'odučiti' starih miselnih vzorcev. 


\section{Nina Tomaževič}

\section{Ravnanje z znanjem v javni upravi}

\subsection{Načini pridobivanja znanja in ovire na poti pridobivanja znanja}

Znanje je mogoče pridobivati na formalne (izobraževanje, usposabljanje) in neformalne načine (učenje na delovnem mestu, učenje ob sodelovanju s sodelavci, konkurenti in drugimi udeleženci $\vee$ poslovanju). Pridobivanje znanja in spretnosti se $\vee$ zadnjem času močno povečuje izven tradicionalnih institucij formalnega izobraževanja in usposabljanja. Obenem se tudi v formalnih oblikah izobraževanja in usposabljanja vse pogosteje uporabljajo pristopi, kot so problemsko učenje, mentorstvo, timsko delo, delavnice, študije primerov in druge oblike učenja, ki temeljijo predvsem na učenju na podlagi izkušenj, tako tujih kot lastnih.

Formalna izobrazba nam daje predvsem temeljno znanje (know-what oz. vedeti kaj) in osnove spodbude za kreativno delo. Večino drugega znanja (know-how oz. vedeti kako in know-why oz. vedeti zakaj) ter motivacijo za kreativno reševanje konkretnih problemov pa pridobimo $z$ delom $\vee$ konkretni situaciji (Možina, 2001, str. 25).

Po mnenju Možine (2001, str. 22) v večini organizacij pridobivanje in izkoriščanje znanja ovira kar nekaj dejavnikov. Najpomembnejši med njimi so počasnost organizacijske prenove, nepripravljenost vodij na spremembe ter neoprijemljivost intelektualnega kapitala, ki ga je zaradi tega težko izmeriti in opredmetiti, kar pa ne pomeni, da ga smemo ignorirati.

\section{Ravnanje z znanjem}

\subsection{Opredelitve ravnanja z znanjem}

Ravnanje z znanjem (Knowledge management) sodi med sodobna orodja menedžmenta, ki jih podjetja $\vee$ zasebnem sektorju razvitega sveta (ZDA, Japonska, Evropa) že desetletja uporabljajo za izboljšanje učinkovitosti, uspešnosti ter poslovne odličnosti. Predvsem v ZDA že dlje časa, v Evropi pa v zadnjih letih uvajajo podobne koncepte tudi organizacije $\vee$ javnem sektorju. Med omenjena orodja za izboljšanje poslovanja, bodisi na področju ravnanja kakovosti, trženja, ekonomike in financ ali ravnanja z ljudmi pri delu, sodijo naslednji primeri:

- Business Excellence Models (modeli poslovne odličnosti)

- TOM (Total Quality Management - ravnanje celovite kakovosti) 


\section{Nina Tomaževič}

- Benchmarking (primerjanje z najboljšimi)

- Benchlearning (primerjalno učenje)

- CRM (Customer Relationship Management - ravnanje odnosov s strankami)

- $\quad$ ERP (Enterprise Resource Planning - planiranje virov podjetja)

- BSC (Balanced Scorecard - uravnoteženi izkaz poslovanja)

- BPR (Business Process Reengineering - prenova poslovnih procesov)

- KM (Knowledge Management - ravnanje z znanjem).

Pojem ravnanja z znanjem so opredeljevali številni teoretiki, med njimi tudi:

- Davenport in Prusak (1998, str. 53): kot proces, ki je sestavljen iz pridobivanja in ustvarjanja, kodiranja, prenašanja in uporabe znanja z namenom pridobivanja novih priložnosti za podjetje

- Scarbrough, Swan in Preston (1999): kot nameren in sistematičen proces ali pristop k pridobivanju, zajemanju, deljenju in uporabi produktivnega znanja, kjerkoli že obstaja, da bi spodbudili učenje in povečali uspešnost organizacije

- na malo drugačen način Scarbrough, Swan in Preston (1999): kot poslovno filozofijo - kot zbir principov, procesov, organizacijskih struktur in tehnologij, ki ljudem pomagajo pri deljenju in uporabi njihovega znanja pri doseganju njihovih poslovnih ciljev

- Probst, Raub in Romhardt (2000, str. 30): kot proces, sestavljen iz določanja ciljev znanja, ugotavljanja (obstoječega) znanja, pridobivanja znanja, razvijanja znanja, delitve znanja, uporabe in zadržanja znanja; v kontrolo doseženega vključujejo ocenjevanje omenjenih elementov

- Rozman (2001, str. 48): kot zagotavljanje smotrnega ustvarjanja in uporabe znanja (planiranje znanja, uveljavljanje, razvijanje znanja s komuniciranjem, vodenjem in motiviranjem ter kontroliranje znanja)

Von Krogh (2001) je navedel kot ključne procese, povezane z znanjem, katerih namen je doseganje ciljev organizacije:

1. iskanje znanja in zajem obstoječega znanja $v$ organizaciji in $v$ odnosih $z$ udeleženci, npr. skladiščenje podatkov (datawarehousing), rudarjenje podatkov (datamining), rumene strani, sistem uravnoteženih kazalnikov (BSC), revizije znanja (knowledge audits), poslovno-informacijski sistemi ipd.

2. deljenje ali izmenjava prikritega in odkritega znanja med posamezniki in skupinami znotraj in zunaj organizacije (npr. internet, intranet, Lotus 


\section{Nina Tomaževič}

\section{Ravnanje z znanjem v javni upravi}

Notes, mrežna struktura organiziranosti, delavnice, prenos dobrih praks, primerjanje z najboljšimi (benchmarking), kulture deljenja znanja, enote za prenos tehnologij, enote za prenos znanja, sistemsko razmišljanje ipd.)

3. ustvarjanje novega prikritega in odkritega znanja, npr. aktivisti znanja, mreže strokovnih inovacij, novi sistemi ravnanja z ljudmi pri delu (HRM), nove organizacijske vrednote, sistemi ravnanja projektov, akademije znotraj podjetij, Cop (Communities of practice) ipd.

Ravnanje z znanjem torej ne pomeni le skladiščenja podatkov ali skrbi za usposabljanje zaposlenih. Postaja eno ključnih orodij sodobnega menedžmenta, tako $v$ zasebnem kot javnem sektorju.

\subsection{Ali prinaša koncept ravnanja z znanjem kaj novega?}

Ravnanje z znanjem je dandanes široko in pogosto uporabljen pojem, obenem pa obstaja $\vee$ zvezi z njim precejšnja zmeda. Mnogi namreč menijo, da ravnanje z znanjem ni nič novega, zato $v$ nadaljevanju prispevka sledi nekaj pogledov, ki to razmišljanje argumentirajo.

Rozman (2001, str. 43) navaja, da je znanje osrednja tema proučevanja filozofije in epistemologije od 400 let pred našim štetjem. Kar je novo, meni Takeuchi (2001, str. 313), je zamisel o združevanju znanj posameznikov in širitev znanja $\vee$ organizaciji in da gre torej za proučevanje kolektivnega znanja organizacije.

Po mnenju OECD (O'Riordan, 2005) je ravnanje z znanjem preprosto uporaba uveljavljenih orodij menedžmenta, npr. menedžmenta uspešnosti pri delu (performance management), ravnanja z ljudmi pri delu (HRM), nove priložnosti, ki jih ponujata informacijska in komunikacijska tehnologija ipd., da bi izboljšali razširjanje znanja znotraj organizacije in $v$ njenem okolju. Vendar to ne pomeni, da s tem razmišljanjem namigujejo, naj organizacije le čakajo, da se bo ravnanje z znanjem 'kar zgodilo'. Ravnanje z znanjem namreč zahteva precejšen napor in spremembe $\vee$ organizacijah. Izkušnje so pokazale, da razvoj dobre strategije ravnanja z znanjem sistematično vključuje vsa orodja menedžmenta, ki so na voljo najvišjemu vodstvu. 
Nina Tomaževič

Ravnanje z znanjem $v$ javni upravi

Tabela 1: Resnice in zmote o 'ravnanju z znanjem'

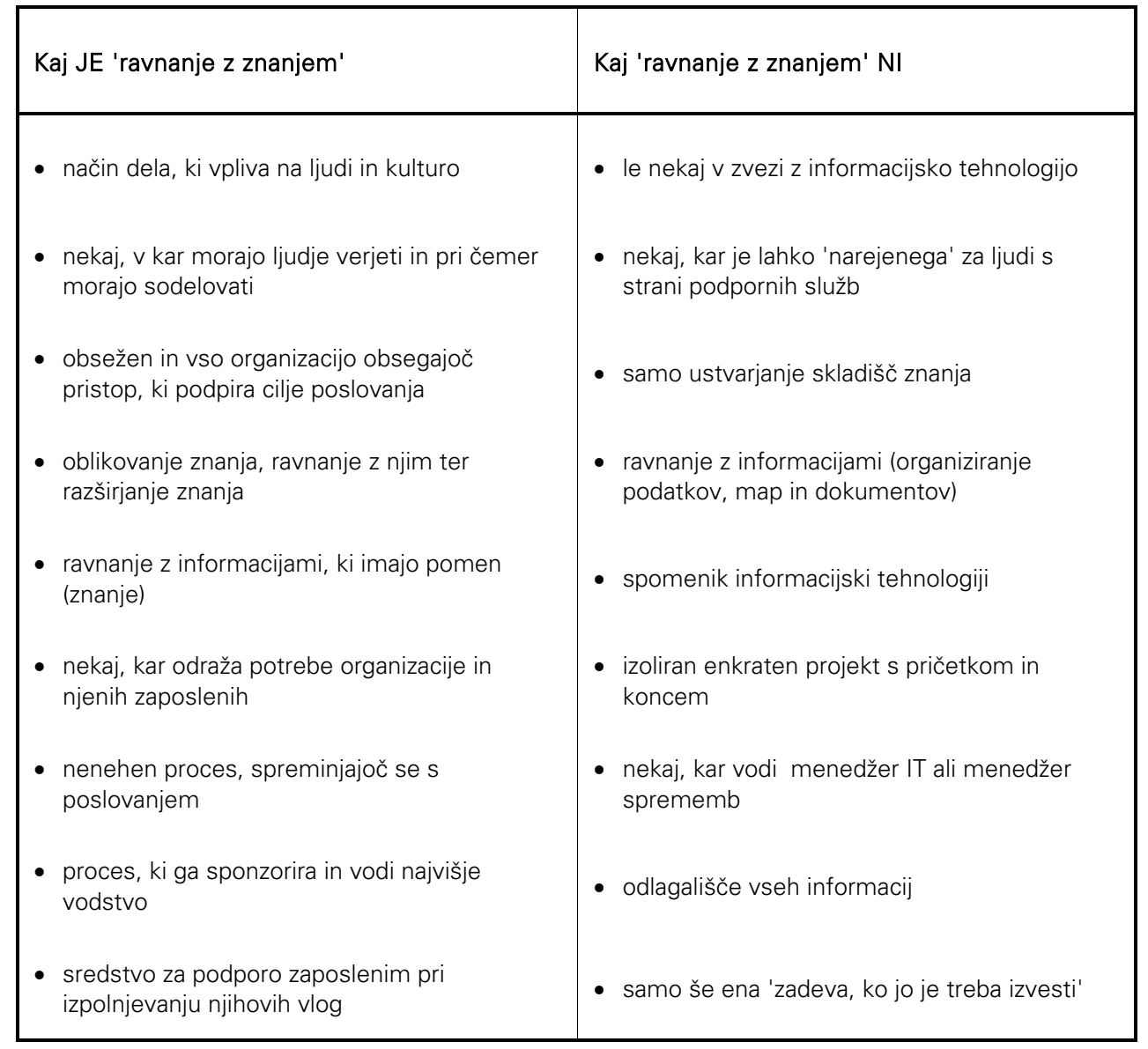

Vir: IBM (2004)

Znanje $\vee$ organizacijah torej obstaja že od nekdaj. V zadnjih desetletjih pa potreba po ravnanju z znanjem kot sistematični strategiji/orodju postaja vse bolj nujna, in sicer iz naslednjih razlogov (Foray, Gault, 2003):

- nekateri stari pristopi na področju ravnanja z ljudmi pri delu ne 'delujejo' več (za pomnenje in prenos znanja s starejših na nove sodelavce danes ni več časa, zato ju nadomešča 'zapisani spomin', npr. priročniki, ekspertni sistemi, dokumenti za vzdrževanje);

- nujnost inoviranja kot pogoja za preživetje je povzročila uvedbo določenih oblik ravnanja z znanjem (planirane strategije za zbiranje in dokumentiranje idej in predlogov zaposlenih, procesi za spodbujanje kreativnosti);

- povečanje trga znanja (problem patentiranja intelektualne lastnine), širjenje uporabe informacijske tehnologije in nove metode za vrednotenje 
Nina Tomaževič

Ravnanje z znanjem v javni upravi

neotipljivih (intangible) sredstev prav tako zahtevajo uvedbo določenih metod ravnanja z znanjem;

- razumevanje pojava, ki se nanaša na učenje in prenos znanja, se povečuje, kar prinaša priložnosti za uvajanje novih orodij in tehnik ravnanja z znanjem;

- poleg ekonomskih vidikov in vidikov menedžmenta nekateri sociologi trdijo, da mora kapitalizem tistim, ki prispevajo v ekonomskih aktivnostih (še posebej najvišjim ravnateljem in izkušenim inženirjem), nuditi razloge za vznemirjenost in motiviranost.

\subsection{Koristi, ki jih ravnanje z znanjem prinese organizaciji}

Mnoga podjetja, ki so ravnanje z znanjem že prepoznala kot najpomembnejši vpliv na uspešnost poslovanja, so med koristi, ki jih ravnanje z znanjem prinaša, navedla (Davenport, Prusak, 1998, str. 153-159, Smith, Irving, 1997, str. 4):

- boljše odločitve

- hitrejše odzivanje na probleme

- povečanje konkurenčne prednosti podjetja

- izmenjavo izkušenj in znanj

- ustvarjanje novih poslovnih priložnosti

- privlačnost podjetja za zaposlene in nove sodelavce

- večjo produktivnost

- zmanjšanje stroškov

- povečanje dobička

- povečanje vrednosti delnice podjetja.

Peters (v: Guns, 1996, str. 15) pravi, da je uspeh podjetja neposredno sorazmeren ustvarjenemu znanju podjetja, hitrosti ustvarjanja znanja in stopnji uporabe znanja.

\subsection{Vpliv menedžerja na proces ravnanja z znanjem}

Odgovornosti za razvoj znanj in sposobnosti danes ne moremo več prenašati na nadrejene, saj je skrb za lasten razvoj vedno bolj stvar vsakega posameznika. Je pa pri zagotavljanju potrebne infrastrukture, ki podpira razvoj zaposlenih, vloga menedžerjev ključnega pomena. Težko bi rekli, da ima pri tem $\vee$ organizaciji kdo večjo in pomembnejšo vlogo, kot jo imajo menedžerji. 


\section{Nina Tomaževič}

Ravnanje z znanjem $v$ javni upravi

Na zaposlene vplivajo kot mentorji in vzorniki, oblikujejo vizijo in vplivajo na kulturo organizacije ter določajo motivacijski in nagrajevalni sistem $\vee$ organizaciji (Pirc, 2001, str. 31).

Pri ravnanju z znanjem se pomembnost menedžerja kaže prav $\vee$ vsaki fazi procesa. $\vee$ fazi ustvarjanja znanja oz. učenja kot vodja, mentor, trener in vzornik omogoča in spodbuja vključevanje zaposlenih. $V$ fazi kodiranja, ko se znanje preoblikuje $\vee$ prenosljivo obliko, se njegova vloga arhitekta kaže skozi odločitve o uporabi primerne tehnologije in s tem izgradnji potrebne infrastrukture. $V$ fazi prenašanja znanja je menedžer predvsem vzornik, svetovalec in koordinator, ki pokaže različne možnosti komunikacije za delitev znanja med zaposlenimi in jih med seboj usklajuje. Pri uporabi znanja pa se pojavlja predvsem kot vzornik in uspešen oblikovalec novega znanja.

Poseben problem, povezan z ravnanjem z znanjem, je motiviranost za deljenje posameznikovega znanja $z$ drugimi $v$ organizaciji. Spodbujanje deljenja znanja ni lahka naloga, saj je pripravljenost posameznika, da bi delil svoje znanje, ena večjih preprek. Kljub številnim prispevkom na temo organizacijskega učenja in ravnanja z znanjem je narava odnosa med posameznikovo motiviranostjo in deljenjem znanja znotraj organizacije precej neraziskana tema, ki je še posebej zahtevna in zanimiva $\vee$ primeru javne uprave.

\section{Sistemi za ravnanje $z$ znanjem}

Sitar (v: Možina, Kovač, 2006, str. 64) navaja, da so strokovnjaki, ki so se v zadnjih desetletjih ukvarjali z ravnanjem z znanjem, prvotno postavljali $v$ ospredje predvsem odkrito znanje in podporo informacijske tehnologije (sistemov za ravnanje z znanjem - knowledge management systems) za njegov prenos in shranjevanje. Danes velja, da je za organizacije največje vrednosti prikrito znanje, ki ga ni mogoče kodirati, zapisati $\vee$ baze, diagrame, knjižnice in podobno, zato ostane neodkrito in nedostopno. Pa vendar ostajajo informacijska tehnologija in sodobni sistemi za ravnanje $z$ znanjem pomemben vidik uspešnega pristopa $\mathrm{k}$ ravnanju z znanjem $v$ organizaciji.

Informacijska tehnologija je $\vee$ procesu prenosa znanja nepogrešljiva. Omogoča komuniciranje znotraj organizacije ter zunaj nje, obdelavo podatkov, informacij in znanja, shranjevanje znanja ter vpliva na velik porast prenosa znanja med zaposlenimi. Deloma omogoča tudi uporabo znanja, zelo pomembna pa je pri shranjevanju in zaščiti znanja (Černelič v: Možina, Kovač, 2006, str. 8590). 


\section{Nina Tomaževič \\ Ravnanje z znanjem $v$ javni upravi}

Mnogi avtorji, med njimi Haynes (2005, str. 131) opozarjajo, da je za učinkovito in uspešno rabo koncepta ravnanja z znanjem nujna vizija organizacije, temelječa na ljudeh in usmerjena na ustvarjanje ter uporabo idej, ne pa na kontroliranje toka informacij, kar mnoge organizacije pojmujejo pod obravnavanim pojmom in zadevo zožijo le na uporabo ustrezne informacijske tehnologije. Tehnološki pristop k ravnanju z znanjem temelji na skladiščenju znanja (podatkov in informacij). Običajno gre za proizvod informacijske tehnologije, ki shranjuje znanje in ga posreduje tistim, ki ga potrebujejo.

Davenport in Prusak (1998, str. 173) pravita, da je pretirana usmerjenost na tehnologijo pri ravnanju z znanjem najpogostejša nevarnost. Mnogi 'pristanejo' (le) na tehnologiji zato, ker je ni težko kupiti, vpeljati in meriti.

Skladišče znanja skuša zajeti informacije. Ključna dejstva in dokumenti so shranjeni, ažurirani in ustrezno posredovani. Nekateri vidiki, vključeni v ravnanje z znanjem v primeru učinkovitega skladiščenja znanja, so (Haynes, 2005, str. 132):

- ustvarjanje dobre dinamike med tehnologijo in ljudmi, da lahko čim večje število ljudi z uporabo tehnologije pridobi koristi. To pogosto pomeni, da mora biti tehnologija preprosta

- kodiranje dokumentov in informacij, da jih lahko ljudje prispevajo in jih vračajo ob uporabi podobne logike

- ustvarjanje standardnih šablon/obrazcev/predlog in oblik, ki prispevajo k redu in stabilnosti, ne da bi zavirali kreativnost

- ustvarjanje spodbud, da bi ljudje sodelovali

- ustvarjanje spodbud, da bi ljudje uporabljali že pridobljeno znanje, ne pa, da bi ponovno odkrivali podobne procese, ki so že bili odkriti preko izkušenj drugih

- vedenje o tem, kako globoko povezati metodo skladiščenja s strategijo poosebljanja, pri kateri se dokumente identificira z ljudmi, ti ljudje pa so razglašeni za strokovnjake, ki lahko svetujejo tistim, ki morajo izvajati podobne organizacijske procese.

\section{Ravnanje z znanjem in novi javni menedžment}

Od začetka zgodnjih 90-ih let prejšnjega stoletja vodilna podjetja zasebnega sektorja razvijajo postopke, s katerimi zagotavljajo učinkovito ustvarjanje, zajemanje in razširjanje informacij in znanja ter spodbujajo uporabo znanja. Za organizacije javnega sektorja obstaja miselnost, da so se $\mathrm{s}$ konceptom ravnanja $z$ znanjem začele ukvarjati kasneje, vendar ravnanje z znanjem mnogim organizacijam 
javnega sektorja ni tuj pojem, saj imajo posamezni deli, na primer kopenska vojska, mornarica in zračna obramba strategije ravnanja z znanjem že razvite.

Kot odgovor na naraščajoči pritisk za izboljšanje učinkovitosti in uspešnosti ob naraščajočem zavedanju pomembnosti uporabe znanja med organizacijami javne uprave in da bi ohranili vpogled $v$ javno upravo kot celoto $v$ primeru določanja politik in izvedbe storitev, se ravnanju z znanjem tudi v javni upravi posveča vedno večja pozornost.

$\checkmark$ zadnjih letih je ravnanje $z$ znanjem postalo pomembna tema javnega menedžmenta. Organizacije javnega sektorja imajo drugačne motive, prednosti in slabosti $\vee$ primerjavi z organizacijami zasebnega sektorja pri ravnanju z znanjem. Na eni strani sta pritisk konkurence in motiv za zniževanje stroškov običajno manj pomembna, prav tako so rezultati manj jasni in težje merljivi. Poleg tega so vodilne strukture precej hierarhične, kar zmanjšuje navdušenost za inovacije in timsko delo. Na drugi strani so aktivnosti organizacij javnega sektorja običajno delovno-intenzivne oz. temelječe na znanju. Pri tem sta zaradi zainteresiranosti širše javnosti dostop do znanja in preglednost ključnega pomena.

\section{Pregled področij, ki se nanašajo na ravnanje $z$ znanjem v slovenski javni upravi}

\subsection{Ravnanje z znanjem v Strategiji razvoja Slovenije in v Programu reform za izvajanje lizbonske strategije v Sloveniji}

V Strategiji razvoja Slovenije Vlade RS za obdobje 2006 do 2013 je bilo pod točko 'Učinkovita in cenejša država' (Strategija razvoja Slovenije, 2005), med nalogami v Akcijskem načrtu za leti 2005 in 2006 zapisano, da bo za povečanje institucionalne konkurenčnosti, med drugim treba 'načrtno večati učinkovitost in uspešnost javne uprave $s$ spodbujanjem uporabe sodobnih menedžerskih tehnik za vodenje sprememb in doseganje poslovne odličnosti v javnem sektorju; razvijati menedžment človeških virov in znanja; razvijati strateški menedžment (zadolženo Ministrstvo za javno upravo - za leto 2006)'.

$\checkmark$ Programu reform za izvajanje lizbonske strategije $\vee$ Sloveniji loktober 2005) piše, da je program s svojimi cilji in ukrepi usklajen s Strategijo razvoja Slovenije in upošteva predloge Odbora za reforme. $V$ opombi je navedeno, da bodo učinki predlaganega programa celovitih reform na gospodarsko rast po pričakovanjih pozitivni in bodo prve rezultate dali že v letu 2007. 


\section{Nina Tomaževič \\ Ravnanje z znanjem $v$ javni upravi}

Medtem ko je $v$ Strategiji razvoja Slovenije področje ravnanja z znanjem konkretno omenjeno, ga $v$ Programu reform za izvajanje lizbonske strategije $v$ Sloveniji ni mogoče najti. Menimo, da se skriva znotraj prednostnega ukrepa, imenovanega 'uveljavitev sistema strateškega načrtovanja in menedžerskih orodij v javni upravi, uvajanje skupnega ocenjevalnega okvira CAF in vključevanje v EFQM'. Oktobra 2006 je bilo pripravljeno Poročilo o uresničevanju Programa reform za izvajanje lizbonske strategije $v$ Sloveniji. Pod rubriko 'uveljavitev sistema strateškega načrtovanja in menedžerskih orodij $v$ javni upravi, uvajanje skupnega ocenjevalnega okvira CAF in vključevanje $v$ EFOM' je navedeno: ' $V$ okviru uveljavitve sistema strateškega načrtovanja in menedžerskih orodij $v$ javni upravi so bile $\vee$ letu 2005 izdelane metodološke osnove strateškega načrtovanja ter celovitega sistema spremljanja uresničevanja strategij (kazalnikov). Metodološka podlaga in navodila za merjenje uspešnosti e-uprave predstavljajo celovit koncept merjenja uspešnosti e-uprave. Prav tako je bil razvit prototip informacijske podpore za spremljanje merjenja uspešnosti euprave. Na podlagi izkušenj je bil razvit koncept merjenja učinkovitosti izvajanja strateških ciljev Vlade RS, ki temelji na delovnem programu Vlade RS za tekoče leto. Koncept merjenja učinkovitosti izvajanja strateških ciljev Vlade RS temelji na sistemu strateškega načrtovanja' (Poročilo o uresničevanju Programa reform za izvajanje lizbonske strategije $\vee$ Sloveniji, 2006). O menedžerskih orodjih $\vee$ javni upravi ni napisanega nič. V Strategiji razvoja Slovenije za obdobje 2006 do 2013 je bilo navedeno, da je za omenjeno točko, z izvedbo v letu 2006, zadolženo Ministrstvo za javno upravo.

\subsection{Ravnanje z znanjem v okviru nalog Ministrstva za javno upravo}

$\mathrm{Na}$ spletnih straneh so $\mathrm{v}$ predstavitvi Ministrstva za javno upravo navedeni glavni cilji ministrstva $\vee$ mandatu 2004-2008 (Prednostne programske naloge Ministrstva za javno upravo, 2007):

- usmerjenost uprave k uporabnikom; to vključuje k uporabnikom usmerjeno upravno poslovanje, razvoj e-uprave in drugih sodobnih načinov poslovanja z zunanjimi in notranjimi uporabniki in zagotavljanje učinkovitega in konkurenčnega servisa posameznikom, civilni družbi in predvsem slovenskemu gospodarstvu

- učinkovit uslužbenski sistem in pravičen plačni sistem; to vključuje sodoben uslužbenski sistem z vsemi elementi upravljanja kadrovskih virov in pregleden, pravičen, celovit in javnofinančno vzdržen sistem plač $v$ javnem sektorju 


\section{Nina Tomaževič}

- kakovostno in učinkovito poslovanje javne uprave; to zajema vzpostavitev sistema kakovosti $v$ javni upravi, učinkovitost in kakovost na vseh ravneh vladnega in upravnega odločanje $s$ čim manj zaostanki in racionalno poslovanje $z$ bistvenim zmanjšanjem stroškov in z zmanjšanjem števila uslužbencev $v$ civilnem delu državne uprave

- odprtost in preglednost poslovanja celotne javne uprave; to pa obsega preprost, celovit in brezplačen dostop do informacij javnega značaja, dostopnost vseh podatkov o javni porabi in zagotavljanje sodelovanja javnosti pri odločanju.

Druga alineja torej govori o razvoju 'učinkovitega uslužbenskega sistema in pravičnega plačnega sistema, kar vključuje sodoben uslužbenski sistem z vsemi elementi upravljanja kadrovskih virov...'. Ravnanje z znanjem bi moralo biti del tega področja.

Prav tako je na spletnih straneh Ministrstva za javno upravo, in sicer pod rubriko 'Temeljna delovna področja', kot eno izmed delovnih področij navedeno področje 'organizacija javne uprave in kadri' z opisom:

"Slovenija ima zgrajen sistem javne uprave in javnih uslužbencev, ki temelji na veljavni zakonodaji. Reforma slovenske javne uprave, sistemsko vodena od leta 1996, je usmerjena $v$ nadgradnjo obstoječega sistema. Bistvo reformnih procesov je $v$ izboljšanju delovanja slovenske javne uprave $v$ smislu večje strokovnosti, politične nevtralnosti, transparentnosti, učinkovitosti in usmerjenosti k uporabnikom javnih storitev. Eden od pomembnih elementov reforme državne uprave je tudi področje upravljanja kadrovskih virov $v$ smislu zavestnega, načrtnega, sistematičnega in racionalnega ravnanja z ljudmi pri delu. Podlaga za aktivno izvajanje je Zakon o javnih uslužbencih, s katerim se $v$ javni upravi vzpostavlja uslužbenski sistem, ki temelji na izbiri po merilih strokovne usposobljenosti in spodbujanju nadpovprečne delovne uspešnosti" (Temeljna delovna področja MJU, 2007).

Bistvene naloge na področju organizacije in kadrov so (Temeljna delovna področja MJU, 2007):

- sistem, organiziranost in delovanje javne uprave,

- $\quad$ razvoj in izvajanje sistema javnih uslužbencev ter inšpekcijski nadzor nad izvajanjem sistema javnih uslužbencev,

- upravljanje kadrovskih virov s poudarkom na razvoju novih načinov in pristopov,

- priprava in usklajevanje kadrovskih načrtov $v$ organih državne uprave in osebah javnega prava iz 22. člena ZJU, 


\section{Nina Tomaževič}

\section{Ravnanje z znanjem v javni upravi}

- $\quad$ pregled in priprava strokovnih mnenj o predlogih aktov o notranji organizaciji in sistemizaciji organov državne uprave,

- opravljanje strokovnih, administrativnih in tehničnih nalog za podkomisijo za štipendiranje ter organizacija in izvajanje štipendiranja vladnih štipendistov

- izgradnja upravnega kadrovskega informacijskega sistema za podporo upravljanja kadrovskih virov,

- vodenje centralne kadrovske evidence,

- strokovne, tehnične in administrativne naloge za Uradniški svet,

- opravljanje strokovnih nalog, priprava gradiv ter vodenje postopkov iz pristojnosti Komisije Vlade Republike Slovenije za pritožbe iz delovnih razmerii,

- priprava, organizacija in izvedba programov strokovnega usposabljanja in izpopolnjevanja za delo $v$ upravi in opravo strokovnih izpitov.

\subsection{Ravnanje z znanjem in Zakon o javnih uslužbencih}

Do tu navedeni viri ne ponudijo nobenih konkretnih dejstev, iz katerih bi lahko sklepali na uvedbo ali razvoj področja ravnanja z znanjem $v$ slovenski javni upravi. Zakon o javnih uslužbencih (ZJU) predpisuje centralno kadrovsko evidenco (le) državne uprave, v kateri se za javnega uslužbenca vodijo tudi (47. člen) (ZJU, 2007):

- podatki o stopnji izobrazbe, funkcionalnem in specialnem znanju, udeležbi na različnih oblikah izpopolnjevanja in usposabljanja in o opravljenih strokovnih izpitih in preizkusih znanja ter drugi podatki o strokovni usposobljenosti

- podatki o izkušnjah na področju evropskih zadev

- podatki o izvrševanju funkcij, o sodelovanju v projektnih skupinah in o opravljanju drugega dela v interesu delodajalca.

V 51. členu ZJU je navedeno, da drugi državni organi in uprave lokalnih skupnosti lahko vodijo kadrovsko evidenco za svoje potrebe, in sicer vodijo vse ali le nekatere podatke iz 47. člena in da se kadrovske evidence lahko povezujejo, če se državni organi in lokalne skupnosti tako dogovorijo.

Področje, povezano s pridobivanjem znanja in usposabljanjem, je $\vee$ ZJU omenjeno še $v$ členih, ki urejajo pogoje za opravljanje delovnih mest, pogoje za pridobitev položaja, pogoje za imenovanje $v$ naziv ter $v$ poglavju o izobraževanju, usposabljanju in izpopolnjevanju. 103. člen ureja strategijo in načrt izobraževanja, izpopolnjevanja in usposabljanja, 105. člen pa spremljanje kariere in 
strokovnosti dela javnih uslužbencev. 14. poglavje govori o pripravništvu, 22. poglavje pa o strokovnem izpitu za imenovanje $v$ naziv.

\subsection{Drugi prispevki na temo ravnanja z znanjem $v$ slovenski javni upravi}

O ravnanju z znanjem in inoviranju govori model CAF, ki ga za izboljšave $v$ svojem poslovanju uporablja že najmanj 60 organizacij slovenskega javnega sektorja, pretežno upravne enote. Z namenom spodbujanja stremljenja $k$ odličnosti $v$ javni upravi je bil v letošnjem letu začet projekt 'Razvoj in vzpostavitev sistema ocenjevanja odličnosti $v$ javni upravi', ki ga kot partnerji izvajajo Ministrstvo za javno upravo, Urad RS za meroslovje in Fakulteta za upravo. Želja partnerjev je, da bi se uporaba sodobnih pristopov (med katere sodita tudi ravnanje z znanjem in inoviranje) ter kazalnikov razširila med večino organizacij javne uprave.

Miglič (2006) je v prispevku na temo ravnanja z znanjem in njegovim vrednotenjem $v$ javni upravi sicer načela temo ravnanja z znanjem $v$ javni upravi, vendar večji del prispevka opisuje le področje pridobivanja znanja, torej usposabljanja ter vrednotenja učinkov usposabljanja javnih uslužbencev. Navedeno predstavlja le del celovitega pristopa k ravnanju z znanjem. Konkretnejšo sliko stanja na obravnavanem področju bi lahko dobili z nadaljnjimi raziskavami in analizami v posameznih delih javne uprave, saj bo na področju ravnanja z znanjem $v$ prihodnje treba narediti še veliko pomembnih korakov.

Sistematičnega pristopa k ravnanju z znanjem v slovenski javni upravi oziroma njenih delih ali pa člankov in projektov na temo ravnanja z znanjem še ni mogoče najti, zato lahko sklepamo, da je omenjeno področje pri nas kljub temu, da je za uspešnost in odličnost poslovanja ključnega pomena, še precej neobdelano in nerazvito. Glede na to, da je področje ravnanja z znanjem že med zapisanimi cilji in nalogami strateških dokumentov, lahko upamo, da bo kmalu postalo tudi realnost $\mathrm{v}$ vsakdanjiku slovenske javne uprave in jo tudi tako približalo doseganju odličnosti.

\section{Zaključek}

Večina uspešnih podjetij in vse več organizacij javnega sektorja že uporablja številna menedžerska orodja in pristope, ki so jih za potrebe doseganja poslovne odličnosti razvili $v$ poslovnem svetu. Tudi slovenska javna uprava se 


\section{Nina Tomaževič}

\section{Ravnanje z znanjem v javni upravi}

bo morala vse hitreje prilagajati spremembam $v$ okolju in sicer $\mathrm{s}$ prenovo procesov, struktur organiziranosti in organizacijske kulture.

Eno pomembnejših orodij na področju menedžmenta je ravnanje z znanjem, ki je sistematična in načrtna uporaba že znanih orodij, kot so menedžment uspešnosti (performance management), ravnanje z ljudmi pri delu in uporaba sodobnih informacijskih tehnologij s ciljem izboljševanja deljenja znanja znotraj organizacije ter z okoljem.

Reforme slovenske javne uprave so zapisane in so v teku, vendar na področju ravnanja z znanjem še ni mogoče zaslediti večjih korakov. Če izvajalci javnih storitev ne bodo imeli potrebnih znanj oz. sposobnosti ter možnosti za njihovo uporabo, bodo rezultati reform skromni. In ravno zato sta poznavanje in uvedba sistemov ravnanja z znanjem tako pomembna, začenši s posameznikom in nato s posamezno službo ali oddelkom v določeni organizaciji javne uprave kot, končno, z javno upravo kot celoto. Bistvo reform je namreč v njihovem izvajanju.

Nina Tomaževič je na Ekonomski fakulteti diplomirala leta 1996 z nalogo s področja razvoja zmožnosti zaposlenih, magistrirala pa leta 1997 na področju organizacije projektov. Tekom študija je bila demonstratorka na Ekonomski fakulteti, po njem pa se je zaposlila $v$ Banki Slovenije in kasneje $v$ gospodarstvu, obenem pa ostala zunanja sodelavka Ekonomske fakultete, habilitirana kot asistentka za področje menedžmenta in organizacije. Do zaposlitve na Fakulteti za upravo je 5 let delovala na vodstvenih mestih na področju ravnanja s človeškimi viri $v$ dveh največjih slovenskih podjetjih s področja računalniških in informacijskih storitev. Na fakulteti je zaposlena od jeseni 2004, kjer sodeluje pri predmetih s področij organizacije, upravnega poslovanja, menedžmenta in ravnanja s človeškimi viri. 


\section{Nina Tomaževič \\ Ravnanje z znanjem $v$ javni upravi}

\section{Literatura}

- Černelič, M. (2006): 'Procesi pridobivanja, uporabe, prenosa in hranjenja znanja v podjetju' v: Možina, S., Kovač, J. (ur.): 'Menedžment znanja', Založba Pivec, Maribor.

- $\quad$ Davenport, T.H., Prusak, L. (1998): 'Working knowledge: How Organizations Manage What They Know'. Harvard Business School Press, Boston.

- Foray, D., Gault, F. (2003): Measurement of Knowledge Management Practices', OECD, Pariz.

- Guns, B. (1996): The Faster Learning Organization, Jossey Bass Publishers, San Francisco.

- Haynes, P. (2005): 'New Development: The Demystification of Knowledge Management for Public Services', Public Money \& Menedžment, CIPFA.

- Lipičnik, B. (2001): 'Učenje hitrejše od izobraževanja', v: Rozman, R., Kovač, J. (ur.): 'Spreminjanje organizacije in vloga ter ravnanje z znanjem (knowledge management)', 2. znanstveno posvetovanje o organizaciji, Brdo pri Kranju.

- Miglič, G. (2006): 'Ravnanje z znanjem in njegovo vrednotenje v javni upravi' v: Možina, S., Kovač, J. (ur.): 'Menedžment znanja', Založba Pivec, Maribor.

- O'Riordan, J. (2005): 'A Review of Knowledge Management in the Irish Civil Service', Institute of Public Administration, Dublin.

- $\quad$ Pirc, A. S. (2001): 'Pomen ravnateljeve vloge pri oblikovanju ustrezne kulture za ravnanje z znanjem', v: Rozman, R., Kovač, J. (ur.): 'Spreminjanje organizacije in vloga ter ravnanje z znanjem (knowledge management)', 2. znanstveno posvetovanje o organizaciji, Brdo pri Kranju.

- $\quad$ Pollit, C., Bouckaert, G. (2004): 'Public Management Reform', Oxford University Press, Oxford.

- Probst, G., Raub. S., Romhardt, K. (2000): 'Managing Knowledge', Wiley, Chichester.

- Rozman, R. (2001): 'Ravnanje z znanjem in organizacija', v: Rozman, R., Kovač, J. (ur.): 'Spreminjanje organizacije in vloga ter ravnanje z znanjem (knowledge management)', 2. znanstveno posvetovanje o organizaciji, Brdo pri Kranju.

- Scarbrough, H., Swan, J., Preston, J. (1999): 'Knowledge management: a literature review', Institute of Personnel and Development, London.

- $\quad$ Sitar, A.S. (2006): 'Oblike in razsežnosti znanja v organizaciji' v: Možina, S., Kovač, J. (ur.): 'Menedžment znanja', Založba Pivec, Maribor.

- Smith, C., Irving, R. (1997): 'Knowledge Management'. The Institute of Management Foundation, Northants. 


\section{Nina Tomaževič \\ Ravnanje z znanjem $v$ javni upravi}

- $\quad$ Smith, E.A. (2001): 'The role of tacit and explicit knowledge in the workpace'. Journal of Knowledge Management, letnik 5, št. 4, str. 311-321.

- Takeuchi, H. (2001): 'Towards a Universal Management Concept of Knowledge', v: Nonaka, I., Teece, D.,: 'Managing Industrial Knowledge', Sage Publications, London.

Viri:

- $\quad$ IBM, Interno gradivo, 2004.

- Von Krogh, G. (2001): 'Knowledge strategy'. EFQM Forum, Luzerne.

- $\quad$ Prednostne programske naloge Ministrstva za javno upravo.

- $\quad h t t p: / / w w w . v l a d a . s i / i n d e x . p h p ? g r 1=\min \& g r 2=m i n J a v U p r \# p r e d n o s t n e \_p r o g r a m$ ske_naloge', junij 2007.

- Program reform za izvajanje lizbonske strategije $\vee$ Sloveniji. Ljubljana, oktober 2005.

http://www.slovenijajutri.gov.si/fileadmin/urednik/dokumenti/program_reform_i zvajanje_lizbonske.pdf, marec 2007.

- Program reform za izvajanje lizbonske strategije v Sloveniji. Poročilo o uresničevanju programa 2006, Ljubljana, oktober 2006

- $\quad$ http://ec.europa.eu/growthandjobs/pdf/nrp/SL_nrp_sl.pdf, 23.03.2007.

- Skupni ocenjevalni okvir za organizacije v javnem sektorju - CAF 2006,

- $\quad$ http://www.eipa.eu/CAF/CAF_2006/Brochures/Slovania_2006.pdf, junij 2007.

- Strategija razvoja Slovenije 2006 do 2013. Vlada Republike Slovenije, Urad RS za makroekonomske analize in razvoj, Ljubljana, junij 2005.

- http://www.slovenijajutri.gov.si/fileadmin/urednik/dokumenti/strategija_razvoja_ slovenije.pdf, marec 2007.

- Temeljna delovna področja Ministrstva za javno upravo.

- $\quad$ http://www.vlada.si/index.php?gr1=min\&gr2=minJavUpr\#temeljna_delovna_po drocja, junij 2007.

- Zakon o javnih uslužbencih.

- $\quad$ http://zakonodaja.gov.si/rpsi/r07/predpis_ZAKO4827.html, junij 2007. 


\section{SUMMARY}

\section{KNOWLEDGE MANAGEMENT IN PUBLIC ADMINISTRATION}

The expectations of the stakeholders of public administration organisations are increasing due to the changes at all levels of organisations' environment (country level, regional level, global level). Therefore the organisations of public administration are forced and stimulated towards the introduction, implementation and improvement of up-to-date concepts of management in order to increase the efficiency and effectiveness, innovations and business excellence. Public administration will have to become dynamic in order to follow the changes in the environment as well as within themselves. In these circumstances the knowledge is and will be the key strategic asset. In order to improve the services of the public administration the knowledge will have to be efficiently looked for, captured, shared, increased, secured, used and its effect on business performance will have to be checked.

Many organisations have already recognized that their effectiveness and efficiency do not depend only on technology, natural and financial resources, environment and other factors that affect the operations - they are all equally accessible and valid for the majority of the organisations. The future of the organisations depends heavily on the knowledge the employees have today. The understanding of the concept of knowledge management as an every-day functioning of employees and their leaders is the key point which means that the majority of the organisations will have to remodel/transform the current structures and processes of organisation as well as organisational culture.

The article consists of five parts. The first deals with the definition of knowledge, in the second the concept of knowledge management is described and in the third the emphasis is given on knowledge management systems. The fourth part explains the importance of the knowledge management for the public administration and in the fifth the overview of the areas that are connected with the knowledge management in Slovene public administration is given.

There are many definitions of knowledge as well as different understandings of the concept of knowledge management. Knowledge can be defined as the collection of experience, values and information which 
Nina Tomaževič

Ravnanje z znanjem v javni upravi

enables evaluation and the development of the new experience and information (Davenport, Prusak, 1998, p. 5). Knowledge management is an intentional and systematic process or approach for acquisition, sharing and use of productive knowledge in order to stimulate learning and improve the effectiveness of the organisation. This requires the steps such as setting the goals of the knowledge, determining the current knowledge, acquisition of knowledge, the development of knowledge, sharing the knowledge, the use and the capturing of the knowledge as well as the control of all listed elements.

Many companies from the private sector report that the main benefits of knowledge management are better decisions, faster responses to the problems, increased competitive advantage of the company, exchange of experience and knowledge, new business opportunities, benefits for the employees and potential co-workers, increased productivity, lower costs, higher profit and higher shareholder value. Some authors claim that the success of the company is proportional to the produced knowledge of the company, the speed of the knowledge creation and the level of the use of knowledge.

The information technology is indispensable in the process of knowledge transfer. It makes it possible to communicate within and outside the organisation, to analyze the data, information and knowledge, to capture the knowledge and has an enormous impact on the growth of the knowledge of employees. It partially enables the use of the knowledge and is extremely important in the processes of saving and the protection of knowledge.

Knowledge management plays more and more important role also in the public administration. The activities in the public administration organisations are labour-intensive which means that they are based on knowledge. Due to the interests of the wider public the access to the knowledge and the transparency of the knowledge are of the key importance.

Slovene public administration is adapting to the changes in the environment and introducing the modern concepts of management. The last part of the article offers the overview of the areas connected with the knowledge management - in the strategic documents, in the programs and activities of the Ministry for public administration, in the legislation and some (first) projects and articles with the thematics about the discussed theme. 